\title{
ANALISIS FAKTOR-FAKTOR YANG MEMPENGARUHI PERILAKU KONSUMEN DALAM PENGAMBILAN KEPUTUSAN PEMBELIAN KOPI INSTAN
}

\author{
Fityan Mizfar dan Aldon Sinaga
}

\author{
PS. Agribisnis, Fak. Pertanian, Universitas Tribhuwana Tunggadewi \\ Jl. Telaga Warna Blok C Tlogomas Malang 65144 \\ E-mail: a_sinaga@hotmaol.com
}

\begin{abstract}
Coffee (Coffea sp), has an important role as a significant influence in live and livelihood of majority community as well as foreign exchange earner for state. It is known that coffee is one of flagship products in Indonesian commodities, noted that Indonesia is one of the world's largest coffee exporting nation. Instant coffee which is available at this time has been accepted by community which is caused by two factors. First, manufacturers build consumer perceptions that the products are kind of instant coffee beverage that offers practicality in its presentation, and not leaving a coarse powder or residue when drunk. Second, intelligence producers through advertising, where instant coffee is identical with urban culture, modern society, and people who are always busy with various kinds of work which spends time. The research goal was to identify the factors influencing consumer decision in buying instant coffee, especially coffee consumers on internet social networking users, by using Quota NonProbabilistic Sampling. The data analysis in this study used multiple regression analysis. The population was the entire of social networking users both personal and group. The results showed that the factors influencing consumer decisions in buying instant coffee were: sex (1.555), duration of activity or working hours (0.933), education (0.198), and information (0.928). Sex factor (1.555) was dominant to influence consumer decisions in buying instant coffee. This occurred because there was psychological aspect that could pose great effects. It is recommended for entrepreneurs in marketing products through television media to be more enhanced because most consumers find out information about coffee through the media. And for further researchers, it is expected to examine other factors that may affect consumers in making decision in buying instant coffee.
\end{abstract}

Keywords: instant coffee, consumer behavior, decision making

\begin{abstract}
Abstrak: Kopi (Coffea sp), memiliki peran penting karena pengaruhnya yang signifikan dalam hidup dan kehidupan masyarakat mayoritas serta penghasil devisa bagi negara. Kopi merupakan salah satu produk unggulan komoditas Indonesia, tercatat bahwa Indonesia merupakan salah satu negara pengekspor kopi terbesar di dunia. Kopi instan yang ada pada saat ini sudah diterima oleh masyarakat, karena: (1) produsen membangun persepsi konsumen bahwa produk kopi instan adalah jenis minuman yang menawarkan kepraktisan dalam penyajiannya, dan tidak menyisakan serbuk kasar atau ampas bila diminum; (2) kepandaian produsen lewat iklan, dimana kopi instan identik dengan kultur masyarakat kota, masyarakat modern, dan masyarakat yang selalu disibukkan oleh beragam jenis pekerjaan yang menghabiskan waktu. Tujuan penelitian ini adalah untuk mengidentifikasi faktor-faktor yang mempengaruhi keputusan konsumen dalam membeli kopi instan, terutama konsumen kopi di pengguna jejaring sosial internet, dengan menggunakan Quota Sampling NonProbabilistik. Analisis data dalam penelitian ini menggunakan analisis regresi berganda. Populasi adalah seluruh pengguna jejaring sosial baik pribadi maupun
\end{abstract}


kelompok. Hasil penelitian menunjukkan bahwa faktor-faktor yang mempengaruhi keputusan konsumen dalam pengambilan keputusan pembelian kopi instan adalah, jenis kelamin (1.555), lama aktivitas atau jam kerja $(0.933)$, pendidikan $(0,198)$ dan informasi $(0,928)$. faktor jenis kelamin (1.555) lebih dominan menjadi pengaruh keputusan konsumen dalam pembelian kopi instan. Ini terjadi dikarenakan aspek psikologis yang ditimbulkan sangat besar pengaruhnya. Disarankan bagi pengusaha dalam memasarkan produk melalui media televisi untuk lebih ditingkatkan karena sebagian besar konsumen mengetahui informasi tentang kopi melalui media. Dan untuk peneliti selanjutnya, diharapkan untuk meneliti faktor-faktor lain yang dapat mempengaruhi konsumen dalam pengambilan keputusan dalam membeli kopi instan.

Kata Kunci: Kopi Instan, Perilaku Konsumen, Pengambilan Keputusan

\section{PENDAHULUAN}

Kopi (Coffea spp), penting peranannya karena pengaruhnya yang cukup signifikan dalam kehidupan dan penghidupan sebagian masyarakat disamping sebagai penyumbang devisa Negara. Melihat bahwa kopi adalah salah satu komoditas produk unggulan di Indonesia, tercatat bahwa Indonesia adalah salah satu Negara pengekspor kopi terbesar didunia. Usaha produksi kopi merupakan sumber penghidupan jutaan keluarga petanipekebun kopi. Ekspor kopi termasuk sumber penerimaan devisa penting. Indonesia juga tergolong sebagai salah satu sumber penting kopi dunia. Indonesia mampu mengembangkan ekspor ke 89 negara, di berbagai negara tujuan (Badan Pusat Statistik, 2007).

Kopi banyak digemari oleh berbagai kalangan masyarakat, Penggemarnya bukan saja bangsa Indonesia tetapi juga berbagai bangsa di seluruh dunia. Dengan kandungan kafein yang punya daya rangsang terhadap peningkatan kinerja beberapa bagian susunan saraf pusat, minuman kopi pun menjadi jenis minuman yang sangat digemari oleh manusia di berbagai penjuru dunia. .Fakta menunjukkan bahwa kopi merupakan komoditas nomor dua yang paling banyak diperdagangkansetelah minya bumi.

Pertumbuhan kopi olahan di Indonesia secara keseluruhan selama setengah dasawarsa terakhir mengalami peningkatan, dengan ratarata pertumbuhan lebih kurang 5,12 persen (Indocomersial dan BPS, 2008). Survey Litbang Indocomercial tahun 2008 mengungkapkan bahwa porsi jumlah konsumen kopi olahan terbesar di Indonesia adalah lakilaki. Selain itu, kopi olahan dikonsumsioleh anak-anak dan kelompok lanjut usia. Total konsumsi per kapita kopi olahan di Indonesia pada tahun 2008 yaitu 505,9 gram per tahun.

Kopi instan diproduksi karena perubahan pada perilaku minum kopi konsumen. Perubahan pola makan atau minum konsumen, biasanya terjadi pada masyarakat perkotaan. Sebagian besar dari mereka telah disibukkan oleh pekerjaan yang menyita banyak waktu. Mereka tidak lagi mempunyai waktu yang cukup banyak,untuk menyiapkan makanan atau minumannya. Maka dari itu, produk kopi instan yang kini telah diproduksi dan dipasarkan oleh para produsen, merupakan salah satu solusi untuk memenuhi kebutuhan/keinginan konsumen kopi, akan adanya suatu produk minuman kopi, yang mampu memberikan kepraktisan dalam mengkonsumsinya.

Kopi instan yang ada pada saat ini sudah diterima oleh masyarakat,disebabkan oleh dua faktor. Pertama, produsen membangun persepsi konsumen bahwa produk kopi instan adalah jenis minuman yang menawarkan kepraktisan dalam penyajiannya, dan tidak menyisakan serbuk kasar atau ampas bila diminum. Kedua, kepandaian produsen lewat iklan, dimana kopi instan identik dengan kultur masyarakat kota, masyarakat modern, dan masyarakat yang selalu disibukkan oleh beragam jenis pekerjaan yang menghabiskan waktu.

Sebagian masyarakat Indonesia mengalami perubahan pola konsumsi, ke pola konsumsi yang lebih praktis. Hal ini merupakan peluang yang prospektif, bagi produsen kopi instan untuk memasarkan produknya. Melalui iklan dan promosi, produsen berusaha mempengaruhi konsumen, untuk membeli produk yang ditawarkan. Pemasar perlu mempelajari dan memahami perilaku 
konsumen dalam proses keputusan pembelian kopi instan.

Perkembangan kompetisi menunjukkan beberapa produsen kopi mulai melakukan inovasi produk dan kampanye iklan yang cukup besar dan gencar.Program kopi yang sangat intensif diharapkan dapat mempengaruhi minat dan motivasi konsumen. Namun pengambilan keputusan konsumen tidak hanya dipengaruhi oleh produsen dan pemasar, tetapi juga dipengaruhi oleh lingkungan konsumen, perbedaan individu konsumen itu sendiri dan proses psikologis yang terjadi. Oleh karena itu perlu dipelajari dan dilakukan penelitian terhadap perilaku konsumen terutama mengenai faktor apa saja yang menjadi pengaruh konsumen dalam pengambilan keputusan pembelian kopi instan.

\section{METODE PENELITIAN}

Tujuan daripada penelitian ini adalah mengidentifikasi faktor - faktor apa saja yang mempengaruhi keputusan konsumen dalam pembelian kopi instan, dan motivasi konsumen dalam mengkonsumsi kopi instan. Khususnya konsumen sebagai pengguna jejaring sosial internet.

\section{Lokasi dan Waktu Penelitian}

Tempat pengambilan data dalam penelitian ini adalah melalui media jejaring sosial internet baik secara personal maupun grup melalui alamat dibawah ini: https://docs.google.com/forms/d/1vGhg QUhbFTIa1fyR7z4USglxYP6AYn8fhh0

EW5oCApw/viewform, dimulai pada tanggal 11 februari 2013 Pukul 16:13:10 PM -25 Februari 2013 Pukul 13.21.10 PM.

\section{Metode Pengambilan Data/Sampel}

Dalam menentukan besarnya sampel, menurut Arikunto (2005) sampel adalah sebagian atau wakil populasi yang diteliti, Sampel merupakan sebagian dari populasi yang mewakili dari seluruh populasi. Untuk mendapatkan sampel yang refresentatif atau benar-benar mencerminkan populasinya, jika tingkat presentasi yang diinginkan tinggi maka semakin besar pula sampel yang harus diambil, atau semakin besar sampel maka semakin kecil penyimpangan terhadap nilai populasi yang didapat. Selain itu juga, metode pengambilan sampel harus refresentatif dengan sampel yang ada. Metode pengambilan sampel dalam penelitian ini adalah metode "Non Probabilistik Quota Sampling" yaitu teknik pengambilan sampel yang tidak memberikan peluang atau kesempatan sama bagi setiap unsur atau anggota populasi untuk dipilih menjadi sampel berdasarkan kuota waktu yang ditentukan peneliti. Adapun sampel yang ditetapkan dalam penelitian ini sebanyak 346 responden dari populasi.

\section{Definisi Operasional}

1) Umur adalah lamanya tahun yang dilalui responden yang dihitung berdasarkan tahun kelahirannya. 2) Jenis kelamin adalah terdapat dua jenis yaitu laki-laki dan perempuan. 3) Pendidikan responden adalah tingkat pendidikan formal responden, dinilai dari tidak tamat SD sampai pasca sarjana. 4) lama aktivitas atau jam kerja merupakan lama kegiatan yang dilakukan responden dalam hitungan 24 jam perhari. 5) Pendapatan adalah jumlah penghasilan responden dalam satu bulan untuk memenuhi kebutuhan diri sendiri dan keluarganya. 6) informasi merupakan segala sesuatu yang diketahui responden tentang darimana responden mengenal kopi yang dikonsumsinya. (sugiyono, 2007). Instrument penelitian digunakan untuk mengukur nilai variabel yang diteliti dengan tujuan menghasilan data kuantitatif yang akurat dan setiap instrument harus mempunyai skala Teknik pengukuran variabel yang digunakan dalam penelitian ini yaitu menggunakan skala likert. Skala likert digunakan untuk mengukur sikap, pendapatan dan persepsi seseorang atau sekelompok orang tentang fenomena sosial yang ditetapkan secara sfesifik oleh peneliti, yang selanjutnya sebagai variabel penelitian dan pengukuran setiap jawaban variabel menggunakan skala likert dgn gradasi tertentu.

\section{Pengolahan Data}

Data yang terkumpul akan diolah dan dianalisis, adapun tahap tahap dalam pengolahan data adalah sebagai berikut ; 1) koding, semua jawaban yang diberikan oleh responden untuk selanjutnya diberi kode dan dikumpulkan dalam suatu lembaran koding. 2)editing, pada tahap ini dilakukan pengecekan ulang terhadap jawaban responden. 3)entry, 
data yang telah siap dimasukkkan kedalam computer untuk diolah.

\section{Analisis Data}

Dalam penelitian ini Teknik analisa data menggunakan teknik analisis statistik, yaitu dengan menggunakan analisis deskriptif dan analisis regresi berganda.Model analisis ini merupakan analisa yang bersifat kuantitatif, yang digunakan untuk mengetahui sejauh mana besarnya pengaruh antara variabel bebas dengan variabel terikat, baik secara bersama sama maupun secara persial dengan koefesien unstandardized. (sugiyono, 2007)

PERILAKU $=\mathrm{a}+\mathrm{b} 1$ UMUR $+\mathrm{b} 2$ SEX $+\mathrm{b} 3$ DIDIK + b4 JAMKER + b5 PDPTN + b6 INFO+ e. Keterangan : PERILAKU = Keputusan konsumen, UMUR $=$ Variabel umur, SEX = Variabel jenis kelamin, DIDIK = Variabel pendidikan, JAMKER $=$ Variabel jam kerja, PDPTN $=$ Variabel pendapatan, INFO = Variabel informasi. $\mathrm{b}=$ koefesien, $\mathrm{a}=$ Konstanta, e $=$ Standar error uji hipotesis.

\section{PEMBAHASAN DAN HASIL}

Hasil analisis yang mempengaruhi perilaku konsumen dalam pengambilan keputusan pembelian kopi instan (studi kasus pada penggunajejaring sosial internet).

1. Perilaku konsumen dalam pengambilan keputusan pembelian kopi instan

2. Faktor yang mempengaruhi konsumen dalam pengambilan keputusan pembelian kopi instan

Tabel 1. Perilaku Konsumen Dalam Pengambilan Keputusan Pembelian Kopi Instan

\begin{tabular}{|l|c|c|c|c|}
\hline & Coefficients & Standard Error & $\mathrm{t}$ Stat & P value \\
\hline Intercept & -2.3079 & 0.9432 & -2.4469 & \\
\hline SEX & $1.5556^{*}$ & 0.2835 & 5.4865 & 0 \\
\hline UMUR & 0.019 & 0.0337 & 0.563 & 0.5738 \\
\hline DIDIK & $0.1983^{*}$ & 0.0626 & 3.1701 & 0.0017 \\
\hline JAMKER & $0.9331^{*}$ & 0.1496 & 6.2365 & 0 \\
\hline PDPTN & -0.2598 & 0.1502 & -1.7291 & 0.0847 \\
\hline INFO & $0.9283^{*}$ & 0.1102 & 8.4205 & 0 \\
\hline SUmb & & & &
\end{tabular}

Sumber data primer diolah 2013

R2 : 0.6333

* : : Significan

* $\quad$ : nyata pada $\alpha: 0.05$
Hasil analisis menunjukkan Fhit sebesar 37,8336 dengan tingkat signifikansi 0,000 , hal ini berarti secara simultan variabel bebas mempunyai pengaruh secara serempak terhadap variabel tidak bebas. R2 sebesar 0,6333 menunjukkan bahwa sebesar 63,33\% dari variabel tidak bebas (Y) dipengaruhi oleh variabel bebas (X)

Analisis perhitungan koefesien regresi dengan variabel terikat karakteristik konsumen diatas dapat dijelaskan sebagai berikut:

Perilaku $=-2.30793+1.555577$ SEX + 0.0187976 UMUR +0.19833 DIDIK + 0.933139 JAMKER +-0.25979 PDPTN + $0.928265 \mathrm{INFO}$

Dari hasil persamaan regresi linear berganda diatas dapat diketahui karakter apa saja yang mempengaruhi dan tidak berpengaruh pada perilaku konsumen dalam pengambilan keputusan pembelian kopi instan.

Faktor Yang Mempengaruhi Perilaku Konsumen Dalam Pengambilan Keputusan Pembelian Kopi Instan

a. Hubungan jenis kelamin (sex) dengan keputusan konsumen, dapat dilihat pada gambar 1

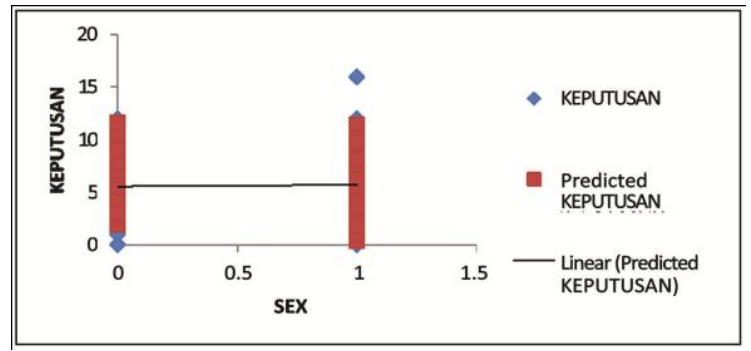

Gambar 1. Hubungan Jenis Kelamin dengan Keputusan Konsumen

b. Koefesien regresi tingkat pendidikan berkorelasi positif dan signifikan pada $\alpha=5 \%$ terhadap perilaku konsumen. Hal ini ditunjukkan bahwa pendidikan mempunyai pengaruh terhadap keputusan konsumen sebesar 0.1983 .

Semakin tinggi tingkat pendidikan konsumen maka semakin tinggi pula keputusan konsumen untuk membeli kopi instan. Hubungan pendidikan (didik) dengan keputusan konsumen dapat dilihat pada gambar 2 . 


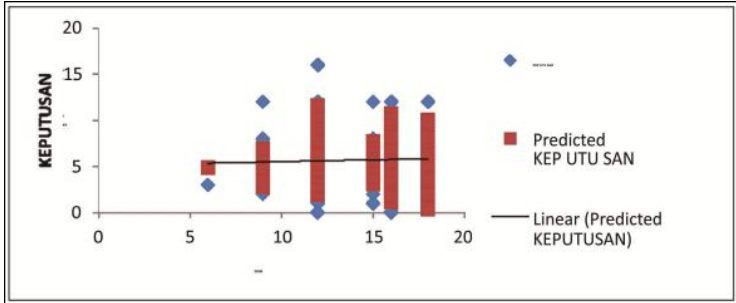

Gambar 2. Hubungan Tingkat Pendidikan dengan Keputusan Konsumen

Jika pendidikan responden dinaikkan menjadi dua kali maka responden dalam mengambil tingkat keputusannya pun akan naik.

c. Koefesien jamker 0.933139 berkorelasi positif dan signifikan pada $\alpha=5 \%$ terhadap perilaku konsumen, hal ini menunjukkan bahwa jam kerja mempunyai pengaruh terhadap keputusan konsumen. Ditunjukkan pada gambar dibawah ini.

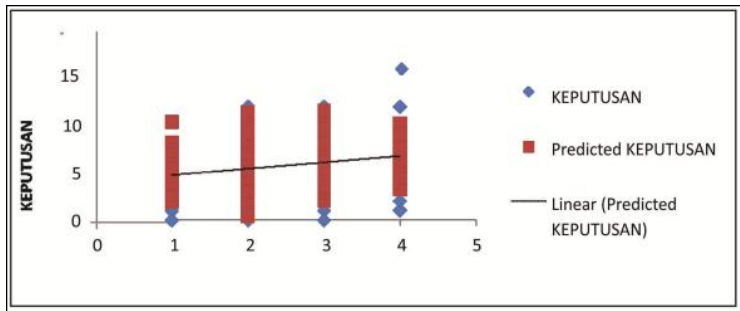

Gambar 3 hubungan jam kerja (jamker) dengan keputusan konsumen

Semakin lama jam kerja seseorang Konsumen maka peningkatan konsumsinya bertambah itu ditunjukkan oleh jika jam kerja ditambah maka keputusan pembelian akan semakin tinggi.

d. Koefesien info 0.928265 berkorelasi positif dan signifikan pada $\alpha=5 \%$ terhadap perilaku konsumen, hal ini menunjukkan bahwa informasi mempunyai pengaruh terhadap keputusan konsumen. Ditunjukkan dengan gambar dibawah ini.

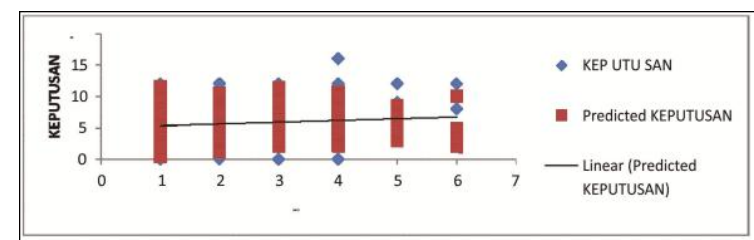

Gambar 4. Hubungan inifo dengan keputusan konsumen

\section{KESIMPULAN}

1. Faktor - faktor yang mempengaruhi keputusan konsumen dalam pengambilan keputusan pembelian kopi instan adalah, jenis kelamin (1.555), lama aktivitas atau jam kerja $(0.933)$, pendidikan $(0,198)$ dan informasi $(0,928)$.

2. Faktor jenis kelamin (1.555) lebih dominan menjadi pengaruh keputusan konsumen dalam pembelian kopi instan. Ini terjadi dikarenakan aspek psikologis yang ditimbulkan sangat besar pengaruhnya

\section{SARAN}

1. Bagi pengusaha

Memasarkan produk melalui media televisi lebih ditingkatkan karena sebagian besar konsumen mengetahui informasi tentang kopi melalui media tersebut.

2. Bagi peneliti selanjutnya

Penelitan selanjutnya diharap dapat mengkaji faktor lain yang mempengaruhi konsumen dalam pengambilan keputusan pembelian kopi instan.

\section{DAFTAR PUSTAKA}

Arikunto Suharsimi. 2005. Manajemen Penelitian. Jakarta : Rineka Cipta.

Arikunto Suharsimi. 2010. Prosedur Penelitian : Suatu Pendekatan Praktis, edisi revisi 2010. Jakarta : Rineka Cipta

Badan Pusat Statistik (BPS). 2007. Indoseia Dalam Angka. Jakarta

Ernawatie, T. 2005. Analisis Ekonomi Pola Konsumsi Kopi Bubuk Konsumen Rumah Tangga.

Skripsi.Departemen Ilmu-Ilmu Sosial Ekonomi Pertanian. Fakultas Pertanian. Institut Pertanian Bogor.

Friza, D. E. T. 2007. Analisis sikap dan faktorfaktor yang mempengaruhi konsumen dalam memilih restoran fast food (Kasus pada Restoran KFC Pajajaran dan A\&W Botani Square Bogor).Skripsi. Program Sarjana Ekstensi Manajemen Agribisnis. 
Fityan Mizfar dan Aldon Sinaga: Analisis faktor-faktor yang mempengaruhi ...

Fakultas Pertanian. Institut Pertanian Bogor.

Hanum, R. 2000. Analisis Lingkungan Usaha dan Bauran Pemasaran dalam Strategi Bersaing Produk Kopi Bubuk.Skripsi.Jurusan Ilmu-Ilmu Sosial Ekonomi Pertanian. Fakultas Pertanian. Institut Pertanian Bogor.

Hawkins D.I, Best R.J, dan Coney K.A. 2001. Consumer Behavior. 8th Ed. Von Hoffmann Press : United States

Herdian. 2005. Kopi Imaji.http:// www.freewebs.com /fer resuga.htm.(23 Mei2008). 2005. Departemen Perindustrian RI (Standar Industri Indonesia No.072483) tentang kopi instan.

Jogiyanto.2004. Metodelogi Penelitian Bisnis, Edisi 2004/2005, Penerbit BPFE. Yogyakarta.

Kartikawati, R. L. 2005. Analisis faktor-faktor yang mempengaruhi keputusan pembelian minuman teh merek frestea. Skripsi.Departemen Ilmu-Ilmu Sosial Ekonomi Pertanian. Fakultas Pertanian. Institut Pertanian Bogor.

Kotler Philip, 2002, Manajemen Pemasaran, edisi millennium,jilid 1, Penerbit PT Prenhalindo, Jakarta.

Kotler, Philip, Gary Armstrong, Dasar-dasar Pemasaran, Jilid 1, (Alih Bahasa: Alexander Sindoro, Indeks, Jakarta, 2003).

Mangkunegara, A. Prabu.2002. Perilaku Konsumen. Penerbit Eresco, Bandung.

Marbun,B.N, 2003, Kamus Manajemen, Penerbit Mediakom, Yogyakarta.

Nirwan Hartadi et al, 2011, Makalah Tentang Kopi Instan, Departemen Teknologi Industri Pertanian Fakultas Teknologi Pertanian Institut Pertanian Bogor Bogor.
Nurhazizah, 2006120008, 2008, Analisis Perilaku Konsumen, Skripsi,Universitas Tribhuana Tunggadewi, Malang.

Nurrayyan Armada, A14105695, 2008, Perilaku Konsumen, Skripsi Itb Bogor.

Rini Dwiastuti, Agustina Shinta, Riyanti Isaskar 2012.Ilmu Perilaku Konsumen, Universitas Brawijaya Press (UB Press), Penerbit Elektronik Pertama dan Terbesar di Indonesia

Sallatu, I. A. 2006. Pangsa Pasar dan Tataniaga Kopi Arabika (di Kabupaten Tanah Toraja dan Enrekang, Sulawesi Selatan).Tesis. Sekolah Pascasarjana. Institut Pertanian Bogor.

Siswoputro, P. S. 1993. Kopi Internasional dan Indonesia.Kanisius.Yogyakarta.

Sugiyono, 2007.Metode penelitian bisnis (pendekatan kuantitatif dan kualitatif) alfabeta. Bandung

Solomon, M.R. 2007. Consumer Behaviour : Buying,Having, and Being, 4th Edition. New Jersey 07548; Prentice Hall

Swasta Basu, Irawan, 2005, Manajemen Pemasaran Modern, Penerbit Liberty, BPFE, Yogyakarta. BPFE:

Wirakusuma, I. P. G. 2006.Analisis Perilaku Konsumen Kopi Banyuatis Serta Implikasinya Terhadap Strategi Pemasaran (Kasus di Perusahaan Kopi Banyuatis, Bali). Skripsi. Program Studi Manajemen Agribisnis. Fakultas Pertanian. Institut Pertanian Bogor.

Waego Hadi Nugroho, 1994, Teknik Penarikan Sampel:Teori Dan Aplikasi, Edisi Pertama, penerbit IKIP Malang.

http://www.aekiaice.org/index.php?option = com _content\&view $=$ article\&id= $5 \&$ Itemid $=11$ \&lang $=$ in

(http://www.kopistory. com/kopi-arabika) (http://www.kopistory.com/kopi-robusta) 